\title{
Identification of Proteins Associated with the Formation of Oral Biofilms
}

Pablo Alejandro Millones-Gómez ${ }^{1}$, Reyma Evelyn Bacilio Amaranto² ${ }^{\circledR}$, Dora Jesús Maurtua

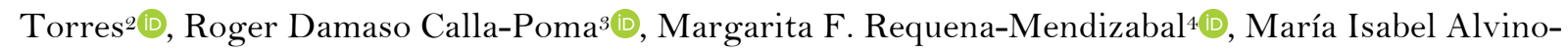
Vales $^{5}$ (D), Rubén Calla-Poma ${ }^{6}$ (D)

\footnotetext{
'Department of Periodontics, Faculty of Dentistry, Universidad Nacional Mayor de San Marcos, Lima, Peru. ${ }^{2}$ Research and Development Laboratories, Universidad Peruana Cayetano Heredia, Lima, Peru.

${ }^{3}$ Department of Oral Rehabilitation, Faculty of Dentistry, Universidad Nacional Mayor de San Marcos, Lima, Peru.

${ }^{4}$ Department of Preventive and Social Stomatology, Faculty of Dentistry, Universidad Nacional Mayor de San Marcos, Lima, Peru. ${ }^{5}$ Stomatology School, Universidad Privada San Juan Bautista, Lima, Peru.

${ }^{6}$ Stomatology School, Universidad Peruana Cayetano Heredia, Lima, Peru.
}

Correspondence: Pablo A. Millones-Gómez, Department of Periodontics, Faculty of Dentistry, Universidad Nacional Mayor de San Marcos, Lima, Peru. E-mail: pablodent@hotmail.com

Academic Editor: Catarina Ribeiro Barros de Alencar

Received: 11 June 2020 / Review: 04 January 2021 / Accepted: 16 February 2021

How to cite: Millones-Gómez PA, Amaranto REB, Torres DJM, Calla-Poma RD, Requena-Mendizabal MF, Alvino-Vales MI, et al. Identification of proteins associated with the formation of oral biofilms. Pesqui Bras Odontopediatria Clín Integr. 202 1; 21 :e0128. https://doi.org/10.1590/pboci.2021.084

\begin{abstract}
Objective: To identify proteins associated with the formation of Streptococcus gordonii and Fusobacterium nucleatum biofilms. Material and Methods: Biofilms composed of two bacterial species, $S$. gordonii and $F$. nucleatum, were cultured for $1,4,7$, and 10 days. The presence of both species was confirmed via amplification of the srtA and radD genes using real-time PCR. The concentrations of proteins associated with the biofilms and individual species were quantified using Western blotting. Results: The protein profiles of S. gordonii and F. nucleatum from individual cultures determined using one-dimensional electrophoresis revealed proteins found in S. gordonii and in F. nucleatum. $\mathrm{Ct}$ and reciprocal $\mathrm{Ct}$ values were determined for the exposed S. gordonii and F. nucleatum biofilms. Glyceraldehyde 3-phosphate dehydrogenase (GAPDH) protein was detected in biofilms and F. nucleatum, whereas HSP40 protein was present only in biofilms after 7 and 10 days of formation. Conclusion: HSP4O was detected only in the formed biofilms; thus, HSP4O is an essential proteins for adhesion.
\end{abstract}

Keywords: Dental Plaque; Fusobacterium nucleatum; Streptococcus gordonii; Genomics. 


\section{Introduction}

The bacterial species of the human oral cavity depend on their ability to bind to surfaces or to each other for colonization. Therefore, proteins involved in adherence are important components that allow microorganisms to form and reside in complex oral biofilms, in which different groups of bacteria perform specific functions. Although microbial interactions within these biofilms trigger important physiological changes in the associated species, including expression of virulence characteristics, the physical interaction through specific adhesins is a key element for the successful initiation of surface colonization and biofilm integration $[1,2]$.

Species of the genus Fusobacterium have been linked to a wide variety of microbial species and are considered important for biofilm formation and architecture. Fusobacteria integrate into biofilms by binding to early colonizers attached to the surface, such as streptococci and actinomycetes. In addition, fusobacteria recruit other bacterial species, including early colonizers and important periodontal pathogens that cannot directly attach to surfaces. This characteristic allows fusobacteria to promote changes in the microbial community and impact their pathogenesis [Q].

Culturable oral fusobacteria are predominantly Fusobacterium periodonticum and Fusobacterium nucleatum. While $F$. periodonticum encompasses only one species, $F$. nucleatum includes five subspecies: nucleatum, polymorphum, fusiforme, animalis, and vincentii. This group of microorganisms thrives not only in subgingival environments [3,4] but also in the supragingival plaque [5]. Streptococci are the most common early colonizers and constitute the main binding partner for fusobacteria recruitment in oral biofilms [6].

The oral cavity is a great model system for studying polymicrobial interactions since it is home to more than 600 different recognized species of bacteria, most of which are considered commensal bacteria [710]. Microorganisms in oral biofilms have been categorized into early and late colonizers. The first colonizing species are mainly gram-positive bacteria capable of adhering directly to the tooth surface and forming the basal layers of the oral biofilm [11-13]. Late colonizers are mainly gram-negative bacteria, including certain periodontal pathogens, such as Treponema denticola, Tannerella forsythia, and Porphyromonas gingivalis, as well as other bacteria within the oral biofilm, forming a complex network of direct or indirect interactions. The spatial distribution of different bacterial species is important in the formation and architecture of oral biofilms. Many of the known oral bacterial species do not directly interact with each other; instead, they interact indirectly through their mutual association with F. nucleatum [14-18].

Recently, interactions of fusobacteria with streptococci have been described; however, the genes involved in the formation of biofilms of different species have not been identified in most of them [19-25]. This study aimed to identify the proteins associated with the adhesion and coaggregation of $F$. nucleatum and $S$. gordonii. In this way, possible targets for future therapies that block the incorporation of pathogenic bacteria can be found, and these targets can be used as the first biomarkers of oral diseases.

\section{Material and Methods}

Culture and Bacterial Strains

Strains of S. gordonii (ATCC 51656) and F. nucleatum (ATCC 10953) were used. The culture medium was $30 \mathrm{~g} / \mathrm{L}$ tryptic soy broth (TSB) in distilled water that was supplemented with artificial saliva [26] (350 $\mathrm{mL}$ of distilled water with $3.15 \mathrm{~g}$ of $\mathrm{NaCl}$ ), a solution of $4 \%$ carboxymethyl cellulose ( $4 \mathrm{~g}$ of carboxymethyl cellulose in $100 \mathrm{~mL}$ of distilled water), and $50 \mathrm{~mL}$ of glycerin. A final volume of $500 \mathrm{~mL}$ was obtained, autoclaved, and stored at $4{ }^{\circ} \mathrm{C}$. 
Establishment of the Dual-Species Biofilm Model

Biofilms were formed on the surface of $25 \mathrm{~mm}$ x $75 \mathrm{~mm}$ transparent rectangular slides placed in $90 \mathrm{x}$ $15 \mathrm{~mm}$ Petri dishes, with one Petri dish per slide. Biofilms were incubated under anaerobic conditions at $37^{\circ} \mathrm{C}$ using AnaeroGen packets in 2.5 L jars (12-Petri-dish capacity) for 24 hours (time 1), 5 days (time 2 ), 7 days (time 3 ), or 10 days (time 4 ).

A colony of each strain was inoculated in $15 \mathrm{~mL}$ of TSB at $37^{\circ} \mathrm{C}$ under anaerobiosis until reaching the exponential growth phase of each strain, i.e., an optical density at $550 \mathrm{~nm}$ of 0.125 (McFarland 0.5 scale), which equals $150 \times 10{ }^{6}$ cells $/ \mathrm{mL}$, which took 4.5 hours for $S$. gordonii and 8 hours for F. nucleatum. Sterile slides were then incubated in Petri dishes with $16 \mathrm{~mL}$ of sterile artificial saliva and equilibrated for 4 hours at $37^{\circ} \mathrm{C}$. The slides were removed with sterile tweezers and washed gently with $15 \mathrm{~mL}$ of phosphate-buffered saline (PBS) ( $\mathrm{pH}$ 7.0, equilibrated) with a sterile $10 \mathrm{~mL}$ pipette, and the slides were placed in new sterile Petri dishes. Then, $100 \mu \mathrm{L}$ of the $S$. gordonii culture was added to each slide and incubated for 1 hour at $37^{\circ} \mathrm{C}$. Next, $100 \mu \mathrm{L}$ of the F. nucleatum culture was added and incubated for 1 hour at $37^{\circ} \mathrm{C}$. Sixteen milliliters of $\operatorname{TSB}\left(37^{\circ} \mathrm{C}\right)$ was added to the slides and incubated at $37^{\circ} \mathrm{C}$ for $1,5,7$, or 10 days [22]. The influence of HSP 40 on aggregation was evaluated [27].

Quantification of F. nucleatum and S. gordonii cells

Genomic DNA was extracted from the cultured biofilms (2.5\%) after 1 day, 4 days, 7 days, and 10 days. The DNA concentration was quantified, and for absolute quantification by real-time PCR, $100 \mathrm{ng} / \mu \mathrm{L}$ was used for all samples to determine the proportion of cells from both species. The oligonucleotides used were [22] srtA F: 5’ TATTATGGTGCTGGTACGATGAAAGAGACTC $\quad 3$ ' and $\quad$ srtA R: 5’ TATAGATTTTCATACCAGCCTTAGCACGATC 3' for $\quad$ S. gordonii and $\operatorname{radD}$ F: 5' GGATTTATCTTTGCTAATTGGGGAAATtATAG 3 , and $\operatorname{radD} \quad$ R: ACTATTCCATATTCTCCATAATATTTCCCATTAGA 3' for F. nucleatum.

\section{Isolation and Quantification of Proteins}

The cells were detached from the glass surface of the Petri dishes by incubating them in trypsin at $37^{\circ} \mathrm{C}$ for 15 minutes and then were harvested by centrifugation at $5000 \times \mathrm{g}$ for 10 minutes at $4{ }^{\circ} \mathrm{C}$. The cell pellet was washed with $1 \times \mathrm{PBS}(\mathrm{pH} 7.4)$. The pellet was resuspended in lysis buffer (50 mM HEPES, 8 M urea, and $1 \mathrm{mM}$ dithiothreitol) and incubated at $95{ }^{\circ} \mathrm{C}$ for 5 minutes. Immediately, the tubes were put on ice, and the cells were lysed by sonication (power of $0.6 \mathrm{~W}$, three 30-second sonications; the samples were kept on ice for 3 minutes between sonications). Cellular debris was pelleted by centrifugation at $720 \times \mathrm{g}$ for 7 minutes at $4^{\circ} \mathrm{C}$, and then, the supernatant was collected and centrifuged at $10,000 \times \mathrm{g}$ for 10 minutes at $4{ }^{\circ} \mathrm{C}$ to pellet the membrane fraction. The supernatant was recovered, from which cytoplasmic proteins were precipitated with absolute ethanol. Five volumes of precooled absolute ethanol were added to the pellet, which was incubated at $70^{\circ} \mathrm{C}$ for 2 hours. Proteins were obtained by centrifugation at $17,000 \times \mathrm{g}$ for 45 minutes at $4{ }^{\circ} \mathrm{C}$, and the pellet was resuspended with lysis buffer. Finally, the proteins were quantified by the Bradford method using a standard curve of known concentrations for bovine serum albumin [22].

Precipitation of Proteins

Two methods were used, one with acetone and one with ethanol. The acetone method consisted of adding five volumes of $100 \%$ acetone to $100 \mu \mathrm{L}$ of sample and incubating at $-20^{\circ} \mathrm{C}$ for 3 hours. The proteins 
were obtained by centrifugation at $15,000 \times \mathrm{g}$ for 20 minutes at $4^{\circ} \mathrm{C}$. The supernatant was discarded, and the pellet was washed twice with $50 \%$ acetone, with centrifugation intervals at $15,000 \times \mathrm{g}$ for 20 minutes at $4^{\circ} \mathrm{C}$. The ethanol method consisted of adding five volumes of precooled absolute ethanol and incubating the sample at $-70^{\circ} \mathrm{C}$ for 2 hours. The proteins were obtained by centrifugation at $17,000 \times \mathrm{g}$ for 45 minutes at $4{ }^{\circ} \mathrm{C}$. The proteins were quantified by the Bradford method and separated by $12 \%$ sodium dodecyl sulfate-polyacrylamide gel electrophoresis (Figure 1) [22].

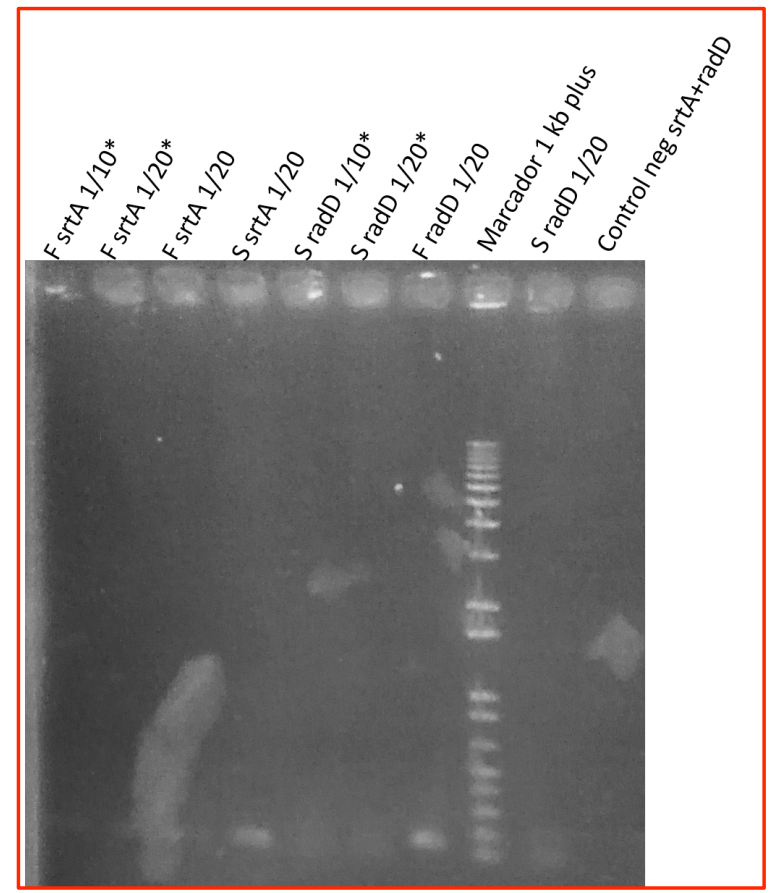

Figure 1. Electrophoresis for srtA and $\operatorname{radD}$ from $F$. nucleatum and S. gordonii.

Immunodetection of HSP4O Using Western Blotting

After separating the membrane or cytoplasmic proteins by $12 \%$ SDS-PAGE, the proteins were transferred to nitrocellulose membranes. The membranes were washed three times with $1 \times \mathrm{PBS}(\mathrm{pH} 7.4)$. Then, general protein blocking was performed with $5 \%$ milk with incubation at $37^{\circ} \mathrm{C}$ for 1 hour in constant motion. The membrane was washed three times with PBS plus $0.05 \%$ Tween 20 at room temperature. Immunodetection was performed by incubating the membrane with an anti-HSP40 antibody (SPA-087, Stressgen Biotechnologies, British Columbia, Canada) (1:1000 dilution in $5 \%$ milk) at $37^{\circ} \mathrm{C}$ for 1 hour. The antibody-antigen complex was detected by incubating the membrane with rabbit anti-mouse $\operatorname{IgG}$ antibody conjugated with horseradish peroxidase (1:2000 dilution in $5 \%$ milk) at $37^{\circ} \mathrm{C}$ for 1 hour. $\beta$-Actin and glyceraldehyde 3-phosphate dehydrogenase $(\mathrm{GAPDH})$ were used as loading controls. The membrane was washed again to remove excess antibodies and finally developed with diaminobenzidine plus $\mathrm{H}_{2} \mathrm{O}_{2}$.

\section{Results}

The quantification of the number of copies of the srtA genes of $S$. gordonii and radD genes of $F$. nucleatum in the biofilm using $\log 10$ Cells by PCR showed an elevated expression of the srtA gene at day 1; however, this increased expression decreased with time. In contrast, the radD gene reached its maximum expression on days 7 and 10 (Figure 2). 


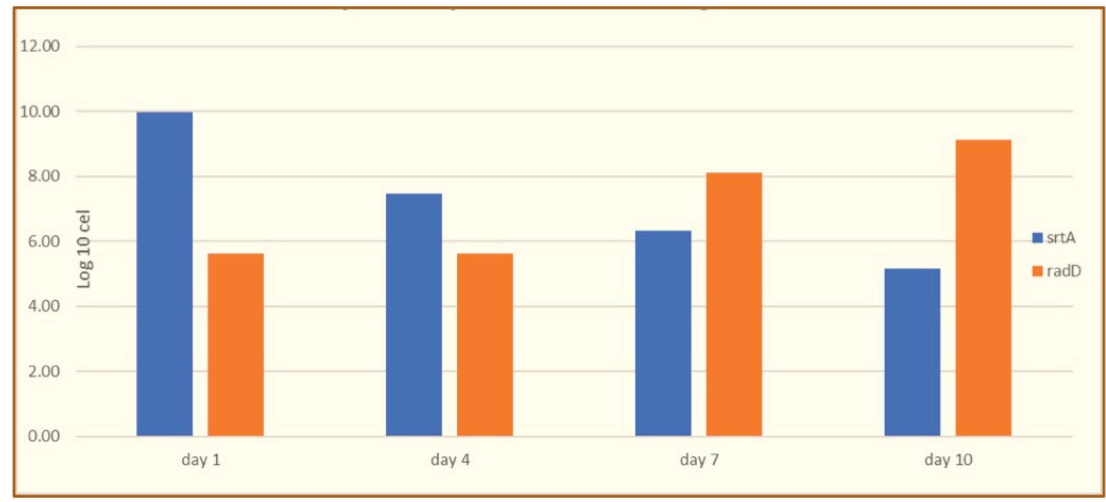

Figure 2. Quantification of the copy numbers of the srtA gene of $S$. gordonii and radD gene of $F$. nucleatum.

The protein profiles of $S$. gordonii and $F$. nucleatum from individual cultures determined using onedimensional electrophoresis revealed proteins found in $S$. gordonii and in F. nucleatum, (Figure 3, red and yellow arrows). Ct and reciprocal $\mathrm{Ct}$ values were determined for the exposed $S$. gordonii and $F$. nucleatum biofilms (Table 1).

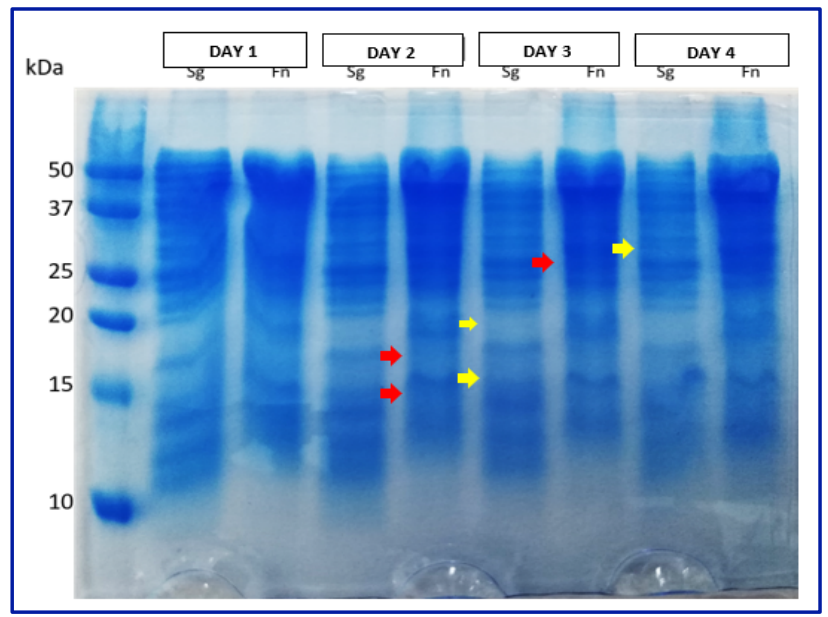

Figure 3. SDS-PAGE of proteins from the cytoplasmic fractions of individual cultures.

Table 1. Ct and reciprocal $\mathrm{Ct}$ values determined for the exposed $\mathrm{S}$. gordonii and F. nucleatum biofilms.

\begin{tabular}{lll}
\multicolumn{1}{c}{ Biofilms } & $\mathbf{C t}$ & $\mathbf{1} \mathbf{C t}$ \\
\hline S. gordonii srtA & 19.757 & 0.051 \\
& 21.528 & 0.046 \\
F. nucleatum radD & 21.714 & 0.046 \\
& 22.189 & 0.045 \\
F+S srtA+radD & 19.554 & 0.051 \\
& 24.739 & 0.040 \\
F+S srtA & 20.429 & 0.049 \\
& 27.758 & 0.036 \\
& 27.133 & 0.037 \\
& 22.179 & 0.045 \\
& 21.647 & 0.046 \\
& 16.732 & 0.060
\end{tabular}




\begin{tabular}{ccc} 
& 22.192 & 0.045 \\
$\mathrm{~F}+\mathrm{S}$ radD & 16.638 & 0.060 \\
& 30.418 & 0.033 \\
& 32.55 & 0.031 \\
& 30.588 & 0.033 \\
\hline
\end{tabular}

The cytoplasmic protein profile of the biofilms harvested after 1, 4, 7, or 10 days of culture remained constant over time and was similar to the profile of the individual culture of $S$. gordonii. However, a higher protein load was observed between 50 and $37 \mathrm{kDa}$ (Figure 4), suggesting the presence of $F$. nucleatum proteins. On the other hand, no drastic changes were observed in the production of any particular protein from either $S$. gordonii or F. nucleatum.

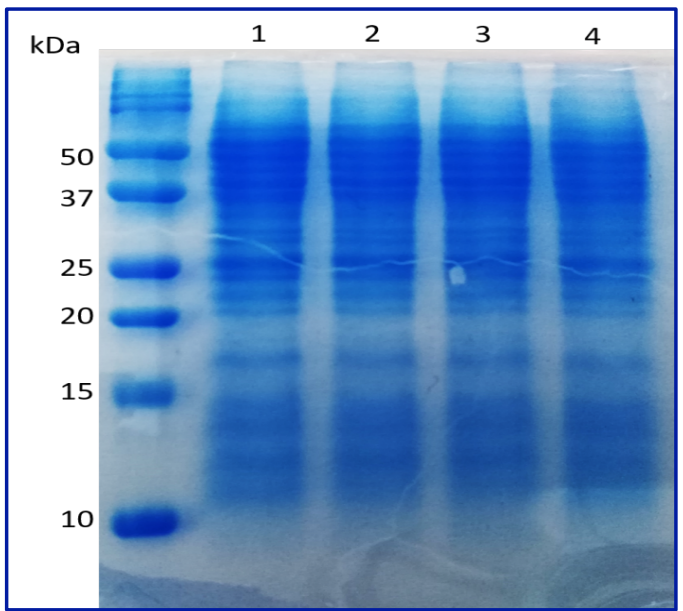

Figure 4. SDS-PAGE of proteins from the cytoplasmic fractions of $S$. gordonii and $F$. nucleatum biofilms.

Through the detection of GAPDH using a specific antibody, it was determined that the antibody detected only an epitope that is found in GAPDH of F. nucleatum and not in GAPDH of $S$. gordonii (Figure 5a). Its molecular weight ranged between 50 and $37 \mathrm{kDa}$. In biofilms, on days 1 and 4, the detection was quite faint compared to that at 7 and 10 days (Figure $5 \mathrm{~b}$ ), confirming that the adherence of F. nucleatum on $S$. gordonii was gradual and complete at 7 days of culture.

HSP40 protein was not detected in individual cultures (Figure 6a) but was detected in biofilms after 7 and 10 days of culture. In these biofilms, its molecular weight ranged from 50 to $37 \mathrm{kDa}$ (Figure 6b), indicating that this protein is involved in coaggregation and, therefore, in biofilm formation.

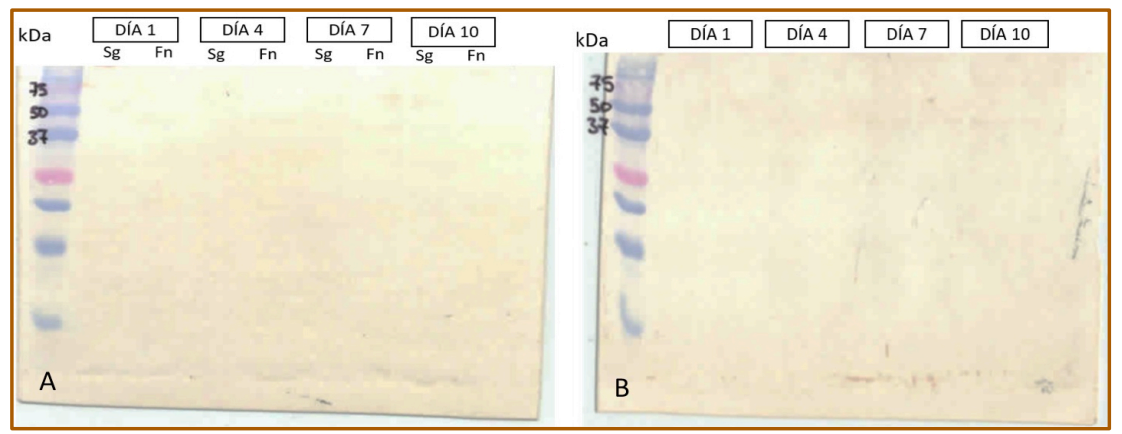

Figure 5. Immunodetection of GAPDH in the cytoplasmic fractions of individual cultures and biofilms. 


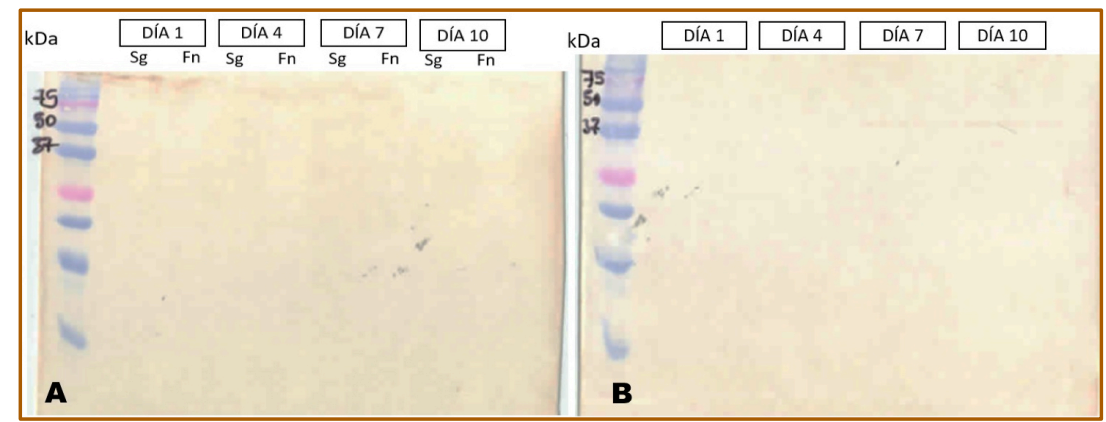

Figure 6. Immunodetection of HSP40 in the cytoplasmic fractions of individual cultures and biofilms.

\section{Discussion}

The development of oral multispecies biofilm implies competition and cooperation between different bacteria. Streptococci are dominant among the first colonizing bacteria, and the second colonizing F. nucleatum can bind and connect these bacteria with late colonization periodontal pathogens, including P. gingivalis, T. denticola, and T. forsythia. Therefore, F. nucleatum plays a crucial role as a bridge in the development of oral biofilms that are associated with periodontitis. Therefore, the identification of proteins that could inhibit the incorporation of $F$. nucleatum in oral biofilms could reduce its pathogenic potential [28-32].

Quantifying the number of copies of the $S$. gordonii srtA gene and F. nucleatum radD gene in the biofilm showed that the gene expression corresponds to the model established by Socransky, who demonstrated that for the development of subgingival biofilms, bacteria capable of adhering to oral surfaces must colonize first, with primary colonizers being initially much more abundant; however, with time, other groups of bacteria proliferate in greater quantity. After the first species die, they provide structural support for biofilm formation and the coaggregation of the other species [5].

Biofilms, which are one way in which such coexistence occurs [26,33], develop based on multiple mechanisms associated with protein expression [34-38]. However, the literature on this subject remains scarce $[18,38,39]$. In this study, we sought to identify proteins associated with the formation of biofilms and determine whether these proteins are found in membranes or the cytoplasm in F. nucleatum and $S$. gordonii biofilms.

In this investigation, the protein profiles of $S$. gordonii and $F$. nucleatum from single cultures determined using one-dimensional electrophoresis revealed that certain proteins were found only in $S$. gordonii but not in F. nucleatum (and vice versa). This finding has been demonstrated in previous studies that have reported the existence of proteins associated with metabolic, nutritional, adherence, and bacterial aggregation functions. The role of proteins in the adherence and coaggregation of microorganisms in biofilms has been demonstrated in two studies [27,40], showing the overexpression of biofilm growth-related proteins, such as the ATP-binding cassette $[41,42]$.

The cytoplasmic protein profiles of the biofilms harvested after 1, 4, 7, and 10 days of cultivation remained unchanged over time, demonstrating that the examined proteins are at constant levels throughout different aspects of biofilm formation, such as cell division, control of cell volume, and control of which substances pass through the cell membrane. These results may be relevant because of the role of these proteins in bacterial resistance to antibiotics [42-46].

Another finding was that HSP40 protein was not detected in individual cultures but was detected in biofilms after 7 and 10 days of culture, as well as the GAPDH protein, indicating that both proteins are 
involved in bacterial coaggregation. These proteins have been reported in previous studies as important elements for linking different bacterial species [47-49].

In summary, both the GAPDH and the $\mathrm{HSP} 40$ proteins regulate coaggregation with S. gordonii. Although the dental plaque biofilm is the result of multiple interactions among oral bacteria, our results indicate that the binding of the secondary colonizer $F$. nucleatum to the primary colonizers can be mediated by the proteins mentioned, which can ultimately influence periodontopathogen binding $[5,6]$.

It is important to note that although the biofilm model used in this study is widely investigated $[25,29,36]$, there are inherent limitations to the ability of these two microorganisms to mimic the complex biofilms that develop in the oral cavity. However, these results indicate that the behavior of biofilms is regulated by the expression of certain proteins. In the future, their identification and location could be potential targets for the application of molecules that can inhibit their expression and therefore the formation of these biofilms

\section{Conclusion}

GAPDH protein was detected only in F. nucleatum samples. GAPDH and HSP40 proteins were detected only in biofilms evaluated after 7 and 10 days of culture and are, therefore, essential proteins for coaggregation.

\section{Authors' Contributions}

\begin{tabular}{|c|c|c|}
\hline PAMG (D) & https://orcid.org/0000-0002-7105-0940 & $\begin{array}{l}\text { Conceptualization, Software, Validation, Resources, Writing - Original Draft, Writing - Review } \\
\text { and Editing, Visualization and Supervision. }\end{array}$ \\
\hline REBA & https://orcid.org/0000-0003-3017-1540 & Conceptualization, Formal Analysis, Investigation and Data Curation. \\
\hline DJMT (iD & https://orcid.org/0000-0001-7198-3778 & Resources, Visualization and Supervision. \\
\hline RDCP (iD & https://orcid.org/0000-0002-5128-212X & Writing - Original Draft and Writing - Review and Editing. \\
\hline MFRM (D) & https://orcid.org/0000-0002-61 13-1990 & Formal Analysis and Investigation. \\
\hline MIAV (iD & https://orcid.org/0000-0001-9014-4005 & Resources and Supervision. \\
\hline $\mathrm{RCP}$ & https://orcid.org/0000-0002-4384-5842 & Methodology and Investigation. \\
\hline
\end{tabular}

\section{Financial Support}

None.

\section{Conflict of Interest}

The authors declare no conflicts of interest.

\section{Data Availability}

The data used to support the findings of this study can be made available upon request to the corresponding author.

\section{References}

[1] Guo L, He X, Shi W. Intercellular communications in multispecies oral microbial communities. Front Microbiol 2014; 5:328. https://doi.org/10.3389/fmicb.2014.00328

[2] Kolenbrander PE, Palmer RJ, Periasamy S, Jakubovics NS. Oral multispecies biofilm development and the key role of cell-cell distance. Nat Rev Microbiol 2010; 8(7):471-80. https://doi.org/10.1038/nrmicro2381

[3] Kook JK, Park SN, Lim YK, Choi MH, Cho E, Kong SW, et al. Fusobacterium nucleatum subsp. fusiforme Gharbia and Shah 1992 is a later synonym of Fusobacterium nucleatum subsp. vincentii Dzink et al. 1990. Curr Microbiol 2013; 66(4):414-7. https://doi.org/10.1007/s00284-012-0289-y

[4] Aruni AW, Dou Y, Mishra A, Fletcher HM. The biofilm community-rebels with a cause. Curr Oral Health Rep 2015; 2(1):48-56. https://doi.org/10.1007/s40496-014-0044-5

[5] Haffajee AD, Socransky SS, Patel MR, Song X. Microbial complexes in supragingival plaque. Oral Microbiol Immunol 2008; 23(3):196-205. https://doi.org/10.1111/j.1399-302X.2007.00411.x 
[6] Kaplan CW, Lux R, Haake SK, Shi W. The Fusobacterium nucleatum outer membrane protein RadD is an arginineinhibitable adhesin required for inter-species adherence and the structured architecture of multispecies biofilm. Mol Microbiol 2009; 71(1):35-47. https://doi.org/10.1111/j.1365-2958.2008.06503.x

[7] Handley PS, Carter PL, Wyatt JE, Hesketh LM. Surface structures (peritrichous fibrils and tufts of fibrils) found on Streptococcus sanguis strains may be related to their ability to coaggregate with other oral genera. Infect Immun 1985; 47(1):217-27. https://doi.org/10.1128/IAI.47.1.217-227.1985

[8] Back CR, Douglas SK, Emerson JE, Nobbs AH, Jenkinson HF. Streptococcus gordonii DL1 adhesin SspB V-region mediates coaggregation via receptor polysaccharide of actinomyces oris T14V. Mol Oral Microbiol 2015; 30(5):41124. https://doi.org/10.1111/omi.12106

[9] Millones-Gómez PA, Maurtua-Torres D, Bacilio-Amaranto R, Calla-Poma RD, Requena-Mendizabal MF, Valderrama-Negron AC, et al. Antimicrobial Activity and Antiadherent Effect of Peruvian Psidium guajava (Guava) Leaves on a Cariogenic Biofilm Model. J Contemp Dent Pract 2020; 21(7):733-40.

[10] Jakubovics NS, Stromberg N, van Dolleweerd CJ, Kelly CG, Jenkinson HF. Differential binding specificities of oral streptococcal antigen I/II family adhesins for human or bacterial ligands. Mol Microbiol 2005; 55(5):1591-605. https://doi.org/10.1111/j.1365-2958.2005.04495.x

[11] Dewhirst FE, Chen T, Izard J, Paster BJ, Tanner AC, Yu WH, et al. The human oral microbiome. J Bacteriol 2010; 192(19):5002-17. https://doi.org/10.1128/jb.00542-10

[12] Aas JA, Paster BJ, Stokes LN, Olsen I, Dewhirst FE. Defining the normal bacterial flora of the oral cavity. J Clin Microbiol 2005; 43(11):572 1-32. https://doi.org/10.1128/jcm.43.11.5721-5732.2005

[13] Kolenbrander PE, London J. Adhere today, here tomorrow: Oral bacterial adherence. J Bacteriol 1993; 175(11):324752. https://doi.org/10.1128/jb.175.11.3247-3252.1993

[14] Kaplan A, Kaplan CW, He X, McHardy I, Shi W, Lux R. Characterization of aid1, a novel gene involved in Fusobacterium nucleatum interspecies interactions. Microb Ecol 2014; 68(2):379-87. https://doi.org/10.1007/s00248-014-0400-y

[15] He J, Bao Y, Li J, Qiu Z, Liu Y, Zhang X. Nanocomplexes of carboxymethyl chitosan/amorphous calcium phosphate reduce oral bacteria adherence and biofilm formation on human enamel surface. J Dent 2019; 80:15-22. https://doi.org/10.1016/j.jdent.2018.11.003

[16] Ebersole JL, Peyyala R, Gonzalez OA. Biofilm-induced profiles of immune response gene expression by oral epithelial cells. Mol Oral Microbiol 2019; 34(1):10.1111/omi.12251. https://doi.org/10.1111/omi.12251.

[17] Neilands J, Davies JR, Bikker FJ, Svensater G. Parvimonas micra stimulates expression of gingipains from Porphyromonas gingivalis in multi-species communities. Anaerobe 2019; 55:54-60. https://doi.org/10.1016/j.anaerobe.2018.10.007

[18] Mutha NVR, Mohammed WK, Krasnogor N, Tan GYA, Choo SW, Jakubovics NS. Transcriptional responses of Streptococcus gordonii and Fusobacterium nucleatum to coaggregation. Mol Oral Microbiol 2018; 33(6):450-64. https://doi.org/10.1111/omi.12248

[19] Tsutsumi K, Maruyama M, Uchiyama A, Shibasaki K. Characterisation of a sucrose-independent in vitro biofilm model of supragingival plaque. Oral Dis 2018; 24(3):465-75. https://doi.org/10.1111/odi.12779

[20] Egland PG, Du LD, Kolenbrander PE. Identification of independent Streptococcus gordonii SspA and SspB functions in coaggregation with actinomyces naeslundii. Infect Immun 2001; 69(12):7512-6. https://doi.org/10.1128/iai.69.12.7512-7516.2001

[21] Zhou P, Li X, Huang IH, Qi F. Veillonella catalase protects the growth of Fusobacterium nucleatum in microaerophilic and Streptococcus gordonii-resident environments. Appl Environ Microbiol 2017; 83(19):e01079-17. https://doi.org/10.1128/aem.01079-17

[22] Lima BP, Shi W, Lux R. Identification and characterization of a novel Fusobacterium nucleatum adhesin involved in physical interaction and biofilm formation with Streptococcus gordonii. Microbiologyopen 2017; 6(3):e00444. https://doi.org/10.1002/mbo3.444

[23] Shimazu K, Oguchi R, Takahashi Y, Konishi K, Karibe H. Effects of surface reaction-type pre-reacted glass ionomer on oral biofilm formation of Streptococcus gordonii. Odontology 2016; 104(3):310-7. https://doi.org/10.1007/s10266-015-0217-2

[24] Millones-Gómez P, Aguirre A. Efficacy of azithromycin associated with RAR in chronic periodontitis: clinical trial, randomized, controlled, triple blind parallel groups. Rev Esp Cirug Oral y Maxilofac 2018; 40(3):129-34.

[25] Sakanaka A, Kuboniwa M, Takeuchi H, Hashino E, Amano A. Arginine-Ornithine Antiporter ArcD controls arginine metabolism and interspecies biofilm development of Streptococcus gordonii. J Biol Chem 2015; 290(35):21185-98. https://doi.org/10.1074/jbc.M115.644401

[26] Thurnheer T, Karygianni L, Flury M, Belibasakis GN. Fusobacterium species and subspecies differentially affect the composition and architecture of supra- and subgingival biofilms models. Front Microbiol 2019; 10:1716. https://doi.org/10.3389/fmicb.2019.01716

[27] Glover JR, Lindquist S. Hsp104, Hsp70, and Hsp40: a novel chaperone system that rescues previously aggregated proteins. Cell 1998; 94(1):73-82. https://doi.org/10.1016/s0092-8674(00)81223-4 
[28] Hendrickson EL, Wang T, Beck DA, Dickinson BC, Wright CJ, Lamont JR, et al. Proteomics of Fusobacterium nucleatum within a model developing oral microbial community. Microbiologyopen 2014; 3(5):729-51. https://doi.org/10.1002/mbo3.204

[29] Jang YJ, Sim J, Jun HK, Choi BK. Differential effect of autoinducer 2 of Fusobacterium nucleatum on oral streptococci. Arch Oral Biol 2013; 58(11):1594-602. https://doi.org/10.1016/j.archoralbio.2013.08.006

[30] Pensantes-Sangay S, Calla-Poma R, Requena-Mendizabal M, Alvino-Vales I, Millones-Gómez P. Chemical composition and antibacterial effect of Plantago Major Extract on periodontal pathogens. Pesqui Bras Odontopediatria Clín Integr 2020; $20: e 0012$.

[31] Ben Lagha A, LeBel G, Grenier D. Tart cherry (Prunus cerasus L.) fractions inhibit biofilm formation and adherence properties of oral pathogens and enhance oral epithelial barrier function. Phytother Res 2019; 34(4):886-95. https://doi.org/10.1002/ptr.6574

[32] Horiuchi A, Kokubu E, Warita T, Ishihara K. Synergistic biofilm formation by Parvimonas micra and Fusobacterium nucleatum. Anaerobe 2019; 62:102100. https://doi.org/10.1016/j.anaerobe.2019.102100

[33] Lima BP, Hu LI, Vreeman GW, Weibel DB, Lux R. The oral bacterium Fusobacterium nucleatum binds Staphylococcus aureus and alters expression of the staphylococcal accessory regulator sarA. Microb Ecol 2019; 78(2):336-47. https://doi.org/10.1007/s00248-018-1291-0

[34] Zhou Y, Millhouse E, Shaw T, Lappin DF, Rajendran R, Bagg J, et al. Evaluating Streptococcus mutans strain dependent characteristics in a polymicrobial biofilm community. Front Microbiol 2018; 9:1498. https://doi.org/10.3389/fmicb.2018.01498

[35] Arenas Rodrigues VA, de Avila ED, Nakano V, Avila-Campos MJ. Qualitative, quantitative and genotypic evaluation of Aggregatibacter actinomycetemcomitans and Fusobacterium nucleatum isolated from individuals with different periodontal clinical conditions. Anaerobe 2018; 52:50-8. https://doi.org/10.1016/j.anaerobe.2018.05.015

[36] Wu C, Al Mamun AAM, Luong TT, Hu B, Gu J, Lee JH, et al. Forward genetic dissection of biofilm development by Fusobacterium nucleatum: Novel functions of cell division proteins FtsX and EnvC. mBio 2018; 9(2):e00360-18. https://doi.org/10.1128/mBio.00360-18

[37] Couvigny B, Kulakauskas S, Pons N, Quinquis B, Abraham AL, Meylheuc T, et al. Identification of new factors modulating adhesion abilities of the pioneer commensal bacterium Streptococcus salivarius. Front Microbiol 2018; 9:273. https://doi.org/10.3389/fmicb.2018.00273.

[38] Ahn SH, Chun S, Park C, Lee JH, Lee SW, Lee TH. Transcriptome profiling analysis of senescent gingival fibroblasts in response to Fusobacterium nucleatum infection. PLoS One 2017; 12(11):e0188755. https://doi.org/10.1371/journal.pone.0188755

[39] Matos AO, Ricomini-Filho AP, Beline T, Ogawa ES, Costa-Oliveira BE, de Almeida AB, et al. Three-species biofilm model onto plasma-treated titanium implant surface. Colloids Surf B Biointerfaces 2017; 152:354-66. https://doi.org/10.1016/j.colsurfb.2017.01.035

[40] León Rodríguez JA, Vargas Casana ST, Millones Gómez PA. Effectiveness of chlorhexidine and essential oils associated with scaling and root planing in the treatment of chronic periodontitis. Rev Cienc Salud 2020; 18(3):1-11. https://doi.org/10.12804/revistas.urosario.edu.co/revsalud/a.9795

[41] Stephen AS, Millhouse E, Sherry L, Aduse-Opoku J, Culshaw S, Ramage G, et al. In Vitro effect of porphyromonas gingivalis methionine gamma lyase on biofilm composition and oral inflammatory response. PLoS One 2016; 11(12):e0169157. https://doi.org/10.1371/journal.pone.0169157

[42] Blanco-Olano J, Millones-Gómez PA. Cicatrizing effect of Aloe vera gel with erythroxy coca in animal model. Med Nat 2020; 14(1):65-74.

[43] Peyyala R, Emecen-Huja P, Ebersole JL. Environmental lead effects on gene expression in oral epithelial cells. J Periodontal Res 2018; 53(6):961-71. https://doi.org/10.1111/jre.12594

[44] Song Y, He JZ, Wang RK, Ma JZ, Zou L. Effect of SrtA on interspecies adherence of oral bacteria. Curr Med Sci 2018; 38(1):160-6. https://doi.org/10.1007/s11596-018-1860-y

[45] Wang H, Ai L, Zhang Y, Cheng J, Yu H, Li C, et al. The effects of antimicrobial peptide Nal-P-113 on inhibiting periodontal pathogens and improving periodontal status. Biomed Res Int 2018; 2018:1805793. https://doi.org/10.1155/2018/1805793

[46] Izui S, Sekine S, Maeda K, Kuboniwa M, Takada A, Amano A, et al. Antibacterial activity of curcumin against periodontopathic bacteria. J Periodontol 2016; 87(1):83-90. https://doi.org/10.1902/jop.2015.150260

[47] Park JH, Lee JK, Um HS, Chang BS, Lee SY. A periodontitis-associated multispecies model of an oral biofilm. J Periodontal Implant Sci 2014; 44(2):79-84. https://doi.org/10.5051/jpis.2014.44.2.79

[48] Wang Q, Wright CJ, Dingming H, Uriarte SM, Lamont RJ. Oral community interactions of filifactor alocis in vitro. PLoS One 2013; 8(10):e76271. https://doi.org/10.1371/journal.pone.0076271

[49] Hendrickson EL, Wang T, Dickinson BC, Whitmore SE, Wright CJ, Lamont RJ, et al. Proteomics of Streptococcus gordonii within a model developing oral microbial community. BMC Microbiol 2012; 12:211. https://doi.org/10.1186/1471-2180-12-211 